\author{
Izabela Sołjan \\ Jagiellonian University in Kraków \\ Institute of Geography and Spatial Management \\ i.soljan@geo.uj.edu.pl
}

\title{
THE SANCTUARY AS A MEANS OF ORGANIZING URBAN SPACE: ACASE STUDY OF SELECTED SANCTUARIES IN POLAND
}

\begin{abstract}
This paper attempts to show that a sanctuary can alter urban space. A sanctuary is a very special place because of its religious nature and attracts both pilgrims and tourists. The spatial structure of a sanctuary is determined largely by changes in the volume and nature of pilgrim 'traffic'. Modern pilgrimage centres are becoming more open to visitors who wish to take part in the life of a sanctuary, even if this involves non-religious activities. The sanctuary's religious offering is supplemented with typical tourism attractions. The establishment of a sanctuary affects the development and spatial organization of a city in a variety of ways. Large sanctuaries favour the development of sanctuary service zones that cater for pilgrims. This is also true in Poland. There are, however, some large and midsize sanctuaries that have no additional facilities designed for pilgrims and this is almost always true of regional and national sanctuaries in Poland.
\end{abstract}

Key words: sanctuary, city/town, pilgrimages, Poland.

\section{INTRODUCTION}

Sanctuaries are places of religious devotion with a special purpose. What makes sanctuaries different from other sacred places is their ability to attract pilgrims who will flock to a given sanctuary to see a special object of devotion such as a relic or to experience a blessing effected by a sacred picture. The Dictionary of the Polish Language (SZYMCZAK, ed. 1983) and The Dictionary of Religion (PONIATOWSKI, ed. 1969) define a sanctuary as a sacred place with special cultural meaning. The Catholic Church defined a sanctuary in 1983 as a "church or another sacred place permitted to be used by its director as a place of pilgrimage due to a special object of devotion" (Canon Law, DUDZIAK 1983). This definition is interpreted to mean a church, chapel, cemetery, altar or a grave (DUDZIAK 1983). In reality, a sanctuary can be a much larger complex of buildings and special sites which serve the needs of pilgrims and the general needs of the given sanctuary.

A sanctuary may affect its surroundings in a number of ways. From a purely academic point of view, a sanctuary raises the value of a given area from 'common space' to 'holy space'. ELIADE (1993) calls this a separation of sacrum from profanum.

The geography of religion treats sanctuaries as a means of organizing and managing religion-oriented space as well as a driver of change organizing urban space (PARK 1994, RINSCHEDE 1995).

The establishment of a sanctuary creates sacred space within a given city that can be used by pilgrims and regular tourists alike. Pilgrimages are treated as a part of tourism (JACKOWSKI 1998). In this sense, a sanctuary is a tourism attraction visited by both tourists and religious pilgrims. Pilgrims visit to see religious sites and buildings without paying special attention to the architectural or cultural meaning of the place they are visiting. However, in terms of general tourism value, sanctuaries are more interesting because of their architecture and cultural value.

Sanctuaries have helped cities grow since ancient times. Some of these cities became known as holy cities' including Rome, Varanasi, Jerusalem and Mecca. The sacred places of each major religion can have a significant impact on the establishment and functioning of a city (JACKOWSKI, SOEJAN 2008). The best example of this is Mecca - a city off limits to nonbelievers. There are other cities where only the faithful of a particular religion may enter its temples. This is true of the Shiva Temple in Varanasi and mosques in Qom and Karbala. These sacred places create strictly religious enclaves within each given city. Catholic sanctuaries, on the other hand, are open to all pilgrims and all tourists.

The effect of a sanctuary on the management of urban space depends on a number of factors including:

- history of the sanctuary,

- history of the settlement,

- importance of the sanctuary,

- spatial impact of the sanctuary, 
Tourism 2011, 21/1-2

T a b le 1. Location and origin of selected sanctuaries in Poland

\begin{tabular}{|c|c|c|c|c|c|c|c|}
\hline City & $\begin{array}{l}\text { Popula- } \\
\text { tion }\end{array}$ & Sanctuary & Origin & Impact & $\begin{array}{c}\text { City doundation } \\
\text { date }\end{array}$ & $\begin{array}{c}\text { Sanctuary } \\
\text { foundation date }\end{array}$ & $\begin{array}{l}\text { Location } \\
\text { in the city }\end{array}$ \\
\hline $\begin{array}{l}\text { Bardo } \\
\text { Śląskie }\end{array}$ & 2,758 & $\begin{array}{l}\text { Our Lady of Lower Silesia } \\
\text { the Guardian of Faith }\end{array}$ & $\begin{array}{l}\text { Devotion to the miraculous } \\
\text { figure of the Mother of God }\end{array}$ & regional & $\begin{array}{l}10^{\text {th }}-12^{\text {th }} \text { century approx. } \\
1300\end{array}$ & $11^{\text {th }}$ century & center \\
\hline Białystok & 294,153 & $\begin{array}{l}\text { Our Lady of Mercy } \\
\text { (cathedral) }\end{array}$ & $\begin{array}{l}\text { Picture of Our Lady of Ostra } \\
\text { Brama }\end{array}$ & regional & $15^{\text {th }}$ century $/ 1749$ & $\begin{array}{l}2^{\text {nd }} \text { half of } 20^{\text {th }} \\
\text { century }\end{array}$ & center \\
\hline Białystok & 294,153 & God's Mercy & $\begin{array}{l}\text { Picture of the Merciful Christ, } \\
\text { grave of the blessed Michał } \\
\text { Sopoćko }\end{array}$ & $\begin{array}{l}\text { supra- } \\
\text { regional }\end{array}$ & $15^{\text {th }}$ century / 1749 & 1993 & $\begin{array}{l}\text { urban built-up } \\
\text { zone }\end{array}$ \\
\hline Bochnia & 29,605 & Our Lady of the Rosary & $\begin{array}{l}\text { Devotion to picture of Our } \\
\text { Lady of the Rosary }\end{array}$ & regional & $12^{\text {th }}$ century / 1253 & $17^{\text {th }}$ century & center \\
\hline Częstochowa & 242,300 & Our Lady of Częstochowa & $\begin{array}{l}\text { Devotion to picture of Our } \\
\text { Lady of Częstochowa }\end{array}$ & $\begin{array}{c}\text { inter- } \\
\text { national }\end{array}$ & $\begin{array}{c}3^{\text {th }} \text { century / 1377 Stara } \\
\text { Częstochowa, } 1717 \\
\text { Częstochówka } \\
\end{array}$ & $1382-1384$ & urban area \\
\hline Dukla & 2,126 & St. John from Dukla & relics of St. John from Dukla & regional & $\begin{array}{l}14^{\text {th }} \text { century / } \\
\text { approx. } 1403 \\
\end{array}$ & $17^{\text {th }}$ century & urban area \\
\hline Gniezno & 67,737 & St. Adalbert & Grave of St. Adalbert & national & 8-9 $9^{\text {th }}$ century / 1243 & 998 & $\begin{array}{l}\text { near of historic } \\
\text { center }\end{array}$ \\
\hline Gostyń & 20,512 & Holy Rose of Święta Góra & Picture of the Mother of God & regional & $13^{\text {th }}$ century / 1278 & $16^{\text {th }}$ century & peripheral \\
\hline Kalisz & 107,140 & St. Joseph & Picture of the Holy Family & $\begin{array}{l}\text { supra- } \\
\text { regional }\end{array}$ & $\begin{array}{c}2^{\text {nd }} \text { century, } 9-10^{\text {th }} \text { century } \\
\qquad / 1253\end{array}$ & $17^{\text {th }}$ century & $\begin{array}{l}\text { near of historic } \\
\text { center from } \\
14^{\text {th }} \text { century } \\
\end{array}$ \\
\hline $\begin{array}{l}\text { Kalwaria } \\
\text { Zebrzy- } \\
\text { dowska }\end{array}$ & 4,493 & Passion-Marian & $\begin{array}{l}\text { Way of the Cross, Picture of } \\
\text { Our Lady of the Calvary }\end{array}$ & $\begin{array}{l}\text { inter- } \\
\text { national }\end{array}$ & $1617 / 1617$ & 1602 & peripheral \\
\hline $\begin{array}{l}\text { Kraków - } \\
\text { Łagiewniki }\end{array}$ & 756,183 & God's Mercy & $\begin{array}{l}\text { Devotion to Picture of the } \\
\text { Merciful Christ, Devotion to } \\
\text { St. Faustina }\end{array}$ & $\begin{array}{c}\text { inter- } \\
\text { national }\end{array}$ & $10^{\text {th }}$ century / 1257 & 1970s & urban area \\
\hline $\begin{array}{l}\text { Kraków- } \\
\text { Mogiła }\end{array}$ & 756,183 & The Holy Cross & $\begin{array}{l}\text { Devotion to the Miraculous } \\
\text { Crucifix }\end{array}$ & $\begin{array}{l}\text { supra- } \\
\text { regional }\end{array}$ & $10^{\text {th }}$ century / 1257 & $15^{\text {th }}$ century & peripheral \\
\hline Leżajsk & 14,166 & Our Lady of Consolation & $\begin{array}{l}\text { Picture of Our Lady of } \\
\text { Consolation }\end{array}$ & $\begin{array}{l}\text { supra- } \\
\text { regional }\end{array}$ & $\begin{array}{c}13^{\text {th }}-14^{\text {th }} \text { century } \\
11397 \\
\end{array}$ & $\begin{array}{c}\text { approx. } 16^{\text {th }} \\
\text { century }\end{array}$ & peripheral \\
\hline Limanowa & 14,781 & Our Lady of Sorrow & Figure of Our Lady of Sorrow & regional & \begin{tabular}{|c|} 
beginning of $16^{\text {th }}$ century \\
$/ 1565$
\end{tabular} & $17^{\text {th }}$ century & center \\
\hline Nowy Sącz & 84,475 & \begin{tabular}{|l} 
Our Lady of the \\
Transfiguration \\
\end{tabular} & The Veraicon Picture & regional & $11^{\text {th }}$ century / 1292 & $16^{\text {th }}$ century & center \\
\hline $\begin{array}{l}\text { Piekary } \\
\text { Śląkie }\end{array}$ & 58,832 & Our Lady of Piekary & Picture of Our Lady of Piekary & national & $13^{\text {th }}-14^{\text {th }}$ century / 1948 & $17^{\text {th }}$ century & urban area \\
\hline Szczyrk & 5,500 & $\begin{array}{l}\text { Our Lady the Queen of } \\
\text { Poland }\end{array}$ & Picture of the Mother of God & regional & $17^{\text {th }}$ century / 1973 & $1990 \mathrm{~s}$ & peripheral \\
\hline Trzebinia & 20,102 & Our Lady of Fatima & Figure of Our Lady of Fatima & $\begin{array}{l}\text { supra- } \\
\text { regional }\end{array}$ & $\begin{array}{c}14^{\text {th }}-15^{\text {th }} \text { century } / 2^{\text {nd }} \text { half } \\
\text { of } 18^{\text {th }} \text { century }\end{array}$ & $\begin{array}{l}2^{\text {nd }} \text { half of } 20^{\text {th }} \\
\text { century }\end{array}$ & peripheral \\
\hline Tuchów & 6,528 & Our Lady of Tuchów & Picture of the Mother of God & $\begin{array}{l}\text { supra- } \\
\text { regional }\end{array}$ & $12^{\text {th }}$ century / 1340 & $\begin{array}{l}\text { approx. } 16^{\text {th }} \\
\text { century }\end{array}$ & peripheral \\
\hline Wadowice & 19,288 & $\begin{array}{l}\text { Our Lady of Perpetual Help, } \\
\text { Devotion to the Bless. John } \\
\text { Paul II }\end{array}$ & $\begin{array}{l}\text { The icon of Our Lady of } \\
\text { Perpetual Help }\end{array}$ & $\begin{array}{l}\text { supra- } \\
\text { regional }\end{array}$ & $14^{\text {th }}$ century $/ 14^{\text {th }}$ century & $\begin{array}{l}\text { approx. } 19^{\text {th }} \\
\text { century }\end{array}$ & center \\
\hline Wejherowo & 46,579 & $\begin{array}{l}\text { Our Lady of Wejherowo, } \\
\text { Calvary }\end{array}$ & $\begin{array}{l}\text { Picture of Our Lady of } \\
\text { Wejherowo, Calvary }\end{array}$ & $\begin{array}{l}\text { suprar- } \\
\text { egional }\end{array}$ & $1643 / 1650$ & 1643 & peripheral \\
\hline Zakopane & 26,846 & Our Lady of Fatima & $\begin{array}{l}\text { Copy of the figure of Our Lady } \\
\text { of Fatima }\end{array}$ & national & $\begin{array}{c}16^{\text {th }}-17^{\text {th }} \text { century } \\
/ 1933\end{array}$ & $\begin{array}{l}2^{\text {nd }} \text { half of } 20^{\text {th }} \\
\text { century }\end{array}$ & peripheral \\
\hline
\end{tabular}

S o u r c e: author's own work based on Miasta polskie...(1965), Miejsca święte (1998), as well as the web pages of selected sanctuaries

- size and function of the settlement.

The paper focuses on the evolution of sanctuaries in Poland and their impact on their surroundings. Tables 1 and 2 show the twenty Catholic sanctuaries selected for analysis. The sanctuaries selected differ interms of spatial impact: some are regional in nature, some international. The paper does not focus on sanctuaries exerting only a local impact.

\section{THE ISSUE OF LOCATION}

The location of a given sanctuary is the product of historical factors including issues associated with the establishment of its parent settlement. Political considerations often played a key role in the past. This was especially true of the Middle Ages when religion was inextricably linked to politics. Having a famous 
sanctuary within one's borders increased the political prestige of the government and the local Church authorities. In Poland, the city of Gniezno and the city of Kraków were good examples of this. Gniezno Cathedral and Wawel Cathedral in Kraków were designated sanctuaries primarily for political reasons. The relationship between the church and the state helped these sanctuaries grow and prosper. Each sanctuary was established in the most important part of the city - close to the seat of power. When the city of Kraków became the new capital of Poland, the former capital (Gniezno) began to experience fewer pilgrims and the Sanctuary of St. Wojciech lost some of its importance. In modern times, political considerations are no longer that important, with the possible exception of the communist period in Poland's history from 1945 to 1989.

The presence of church authorities in a given city has a generally positive effect on the establishment of a sanctuary. From a religious perspective, sanctuaries are still treated as privileged places which attract the faithful in large numbers. For this reason, sanctuaries are often established in cities designated as seats of diocesan and metropolitan church authorities. In this case, sanctuaries are often established in the central part of the city.

The Ełk Diocese was established in 1992. Two years later, the local bishop designated the Ełk Cathedral of St. Wojciech as the Diocesan Sanctuary of Our Lady of Fatima. The seat of the Archdiocese of Wilno was moved to Białystok following World War II. This event initiated the development of a devotion to Our Lady of Ostra Brama in the city of Białystok. Białystok Cathedral became designated the Sanctuary of Our Lady of Mercy. The Białystok Diocese became an archdiocese in 1992 and the Bishop of Białystok (Edward Kisiel) pronounced Our Lady of Ostra Brama to be the patron saint of the new archdiocese.

The above-mentioned examples suggest that the location of a sanctuary is often associated with the location of an existing church building which became designated a sanctuary at a certain point of time. The conversion of regular churches into sanctuaries became quite popular during the Baroque during a time when devotion to miraculous pictures became commonplace in Poland. The same trend was not observed in Catholic countries in Western Europe. When a religious picture became known as a miraculous picture, or when a miraculous picture was permanently displayed in a given church, that given church became known as a sanctuary. Examples of this include the sanctuaries in Bochnia, Tuchów and Limanowa small towns with just one church in their centre.

Religious orders in Poland also played a key role in the establishment of sanctuaries. The monastic nature of many religious orders in the Middle Ages required that their convents and monasteries be built outside cities or at their very edge. This changed in the $13^{\text {th }} \mathrm{c}$. when mendicant orders began to settle in the centres of cities, which was the case with the Dominicans and the Franciscans in the city of Kraków (KŁOCZOWSKI 1987). Members of religious orders were generally more active than the local clergy, which made sanctuaries located next to monasteries more popular with pilgrims. Some cities developed in a way that left some sanctuaries outside their borders until modern times. The Sanctuary of Jasna Góra was initially located on a limestone hill quite far from the village of Częstochowa. One reason for this was the ascetic nature of the Order of St. Paul the First Hermit.

The village of Częstochówka grew up around Jasna Góra and merged with Old Częstochowa in the early $19^{\text {th }}$ c. Today the Sanctuary of Jasna Gora is located near the $19^{\text {th }} \mathrm{c}$. centre of the city of Częstochowa. Some sanctuaries managed to maintain their peripheral location. These include Gostyń, Kalwaria Zebrzydowska and Leżajsk (Table 1). In the case of Kalwaria Zebrzydowska, one part of the sanctuary is located in the town and another outside. This is especially true of sanctuaries dedicated to the crucifixion of Christ.

The city of Kraków annexed the village of Mogiła in 1948 along with its sanctuary. The Shrine of Łagiewniki, which became the site of the Sanctuary of God's Mercy, was also built in a village that had been annexed by the city of Kraków in 1941.

When a sanctuary is located in the centre of a city, it can help the city grow. This was especially true in the Middle Ages. Today this is rarely the case but with notable exceptions such as Fatima - a major shrine in Portugal. A good example from the Middle Ages is the Shrine of Bard Śląski, which was taken over by the Cistercians in 1299. The town next to the shrine began to grow rapidly and became officially recognized in 1300. It then grew dynamically thanks to pilgrims until the $19^{\text {th }}$ c. when the Cistercian Order was abolished. The establishment of monasteries dedicated to the crucifixion of Christ gave rise to small towns such as Góra Kalwaria (BOGUCKA, SAMSONOWICZ 1986). However, many sanctuaries remain outside municipal limits despite their prominent role in the development of their 'daughter' settlements, for instance Kalwaria Zebrzydowska and Wejherowo.

The diverse array of factors behind the establishment of a sanctuary is dominated by the issue of religion. A religious event in itself may determine the location of a sanctuary - a location that may or may not be favourable to its future development.

The organization of urban space is affected both by the location of a sanctuary and the manner in which it came into existence. Three basic sanctuary development mechanisms have been identified that determine 
the degree to which urban space is altered by the establishment of a sanctuary:

a) a sanctuary is established at an existing sacred site, which does not meaningfully alter local land use only the inside of the building undergoes changes. In such cases, only the function of the site changes in that it becomes a sanctuary (e.g. Białystok Cathedral).

b) a sanctuary is established at an existing sacred site, however, the site begins to expand thanks to the construction of new churches and pilgrim facilities (e.g. Częstochowa, Kraków-Łagiewniki, Tuchów, Trzebinia).

c) a sanctuary is established at a site not related to religion and creates a new type of sacred space within a city (e.g. Białystok, Sanctuary of God's Mercy, Kalwaria Zebrzydowska, Szczyrk).

\section{STRUCTURE OF THE SANCTUARY - ORGANIZATION OF SACRED SPACE}

From the perspective of religion, the most important part of the sanctuary is the core - also known as the sacred centre. This is the site of the object of devotion or the location of the event that prompted the establishment of the sanctuary. Other parts of a sanctuary may include:

- other sacred sites dedicated to religious devotion such as churches, chapels, field altars, stations of the cross;

- religious sites not related to religious devotion (e.g. convents);

- cultural sites such as museums and observation decks;

- facilities serving pilgrims such as stores selling religious items, hostels and information desks.

In summary, a sanctuary may be described as a sacred establishment centred around a sacred core and featuring other buildings and sites designed for pilgrims as well as general sanctuary operations.

Table 2 shows examples of sanctuary structure. The significance of a sanctuary is usually reflected in its size, and those of national and international standing tend to have large buildings and well-developed grounds. Local and regional sanctuaries tend to be regular parish churches. This is an oversimplification, as sanctuaries tend to develop dynamically and their status can change, not always reflected by observable changes in the organization of their sacred space. The physical size of a sacred establishment is sometimes determined by the nature of the sanctuary involved. Sanctuaries dedicated to the crucifixion of Christ tend to be very large (hundreds of hectares) due to the distribution of sacred sites over large areas (Fig. 1).
The passage of time also plays a meaningful role in the ways that sacred sites are organized and managed. Contemporary sanctuaries tend to be more open to pilgrims and tourists and their non-religious needs as well. Social progress has also affected the ways pilgrims make their pilgrimage. Modern pilgrims demand higher quality accommodation and other features of modern life. While pilgrimages used to be focused within, this is no longer the case, true at both new sanctuaries and very old ones. Older sanctuaries often convert old buildings or parts of old buildings into accommodation for pilgrims. A part of Bard Monastery is now a hostel for pilgrims. Previously restricted buildings at Jasna Góra now serve as museums. The newest sanctuaries and those experiencing rapid growth usually take the form of large sacred complexes focused on both religion and the natural landscape. One possible way to describe them is using the term pilgrimage park. This term is used by MITKOWSKA (2001) to describe some sacred establishments dedicated to to the crucifixion of Christ and appears to be most appropriate. This form of sanctuary development not only applies to sanctuaries in Poland but is even more pronounced at the largest sanctuaries that have evolved in Western Europe since the middle of the $19^{\text {th }}$ c. (Lourdes, San Giovanni Rotondo, Knock, to some extent Fatima). Another key change in the organization of sacred space is a new type of sanctuary which has become popular in the last 30 years. A characteristic feature of the new sanctuary type is a two-storey building with chapels on the ground floor, making it possible to offer different masses to different groups of pilgrims at the same time. There are three sanctuaries of this type in Poland: Kraków-Łagiewniki, Lichen, Sanctuary of God's Mercy in Białystok.

In addition to organizing urban space in a particular way, sanctuaries also offer a variety of activities to both pilgrims and tourists. This offering, in itself, helps cities grow and prosper. In addition to offering religious activities, modern sanctuaries also tend to offer non-religious ones which contribute to their overall development and the overall development of their parent settlements. This includes the opening of pilgrim hostels, museums, permanent and temporary exhibitions that serve to draw pilgrims and tourists to sanctuary grounds.

The following types of sanctuaries (Table 2) have been identified based on spatial organization and the types of activities offered to pilgrims and tourists:

- original sanctuary - pilgrim activity limited to the sanctuary core;

- basic sanctuary - pilgrim activity beyond the sanctuary core limited to a giftshop or hotel;

- developed sanctuary - consists of the sanctuary core and several (2 to 5 ) additional buildings or sites for pilgrims - increased variety of attractions; 
T a b | e 2. Structure of sacred places at selected sanctuaries in Poland

\begin{tabular}{|c|c|c|c|c|c|c|c|c|}
\hline City & Sanctuary & Sacred core & $\begin{array}{l}\text { Other buildings } \\
\text { used for } \\
\text { devotional } \\
\text { purposes }\end{array}$ & $\begin{array}{l}\text { Other religiuos } \\
\text { and cultural sites }\end{array}$ & $\begin{array}{l}\text { Infrastructure } \\
\text { for pilgrims }\end{array}$ & $\begin{array}{l}\text { Other } \\
\text { functions } \\
\text { of the } \\
\text { sanctuary }\end{array}$ & $\begin{array}{c}\text { Type } \\
\text { of sanctuary }\end{array}$ & $\begin{array}{l}\text { Sanctuary zone } \\
\text { or nearby facilities } \\
\text { for pilgrims }\end{array}$ \\
\hline 1 & 2 & 3 & 4 & 5 & 6 & 7 & 8 & 9 \\
\hline $\begin{array}{l}\text { Bardo } \\
\text { Śląskie }\end{array}$ & \begin{tabular}{|l|} 
Our Lady \\
of Lower \\
Silesia the \\
Guardian \\
of Faith \\
\end{tabular} & $\begin{array}{l}\text { The Visitation of } \\
\text { the Mother of God } \\
\text { Church - for 5,000 } \\
\text { faithful }\end{array}$ & $\begin{array}{l}\text { Votive chapel } \\
\text { in a convent }\end{array}$ & $\begin{array}{l}\text { Redemptorist } \\
\text { convent, Museum } \\
\text { of Sacred Art, } \\
\text { mobile Nativity } \\
\text { scene }\end{array}$ & $\begin{array}{l}\text { Pilgrims' hotel in } \\
\text { a part of the } \\
\text { convent ( } 55 \\
\text { beds), religious } \\
\text { items for sale }\end{array}$ & $\begin{array}{l}\text { convent, } \\
\text { parish }\end{array}$ & developed & none \\
\hline Białystok & $\begin{array}{l}\text { Our Lady } \\
\text { of Mercy }\end{array}$ & $\begin{array}{l}\text { Cathedral with } \\
\text { a chapel of Our } \\
\text { Lady of Ostra } \\
\text { Brama } \\
\end{array}$ & none & none & $\begin{array}{l}\text { Religious items } \\
\text { for sale }\end{array}$ & $\begin{array}{l}\text { cathedral, } \\
\text { parish }\end{array}$ & original & none \\
\hline Białystok & $\begin{array}{l}\text { God's } \\
\text { Mercy }\end{array}$ & $\begin{array}{l}\text { Upper Church with } \\
\text { chapels of Our } \\
\text { Lady of Mercy and } \\
\text { Bless. M. Sopoćko. } \\
\text { Lower Church with } \\
\text { chapels of Our } \\
\text { Lady the Queen } \\
\text { of Peace and St. } \\
\text { Faustina }\end{array}$ & $\begin{array}{l}\text { Papal altar, } \\
\text { chapel in parish } \\
\text { building }\end{array}$ & none & $\begin{array}{l}\text { Meeting hall, hotel } \\
\text { rooms in parish } \\
\text { building, gift shop } \\
\text { in the church }\end{array}$ & parish & developed & none \\
\hline Bochnia & $\begin{array}{l}\text { Our Lady of } \\
\text { the Rosary }\end{array}$ & $\begin{array}{l}\text { St. Nicolas Basilica } \\
\text { with a Chapel of } \\
\text { the Mother of God } \\
\end{array}$ & \begin{tabular}{|l|} 
Rosary Square \\
(construction \\
started in 1986) \\
\end{tabular} & none & $\begin{array}{l}\text { Religious items } \\
\text { for sale }\end{array}$ & parish & basic & Pilgrims' hotel \\
\hline $\begin{array}{l}\text { Często- } \\
\text { chowa }\end{array}$ & $\begin{array}{l}\text { Our Lady } \\
\text { of Często- } \\
\text { chowa }\end{array}$ & $\begin{array}{l}\text { Chapel with } \\
\text { a miraculous } \\
\text { painting of the } \\
\text { Mother of God }\end{array}$ & $\begin{array}{l}\text { Basilica, the } \\
\text { Way of the } \\
\text { Cross, Stations } \\
\text { of the Rosary, } \\
\text { Replica of the } \\
\text { Room of the } \\
\text { Last Supper }\end{array}$ & $\begin{array}{l}\text { Convent, Pauline } \\
\text { Fathers, Treasury, } \\
\text { Knights' Hall, } \\
\text { National Historical } \\
\text { Museum, John } \\
\text { Paul II Hall, } \\
\text { Kordecki Hall, } \\
\text { tower, walls }\end{array}$ & $\begin{array}{l}\text { Jasna Góra } \\
\text { Information } \\
\text { Center, store with } \\
\text { religious items, } \\
\text { baggage lockers }\end{array}$ & convent & complex & \begin{tabular}{|l|} 
Sanctuary zone, \\
Pilgrims' Hotel, several \\
religious gift shops, \\
vendors on St. \\
Barbara Street, 11 \\
restaurants/cafes, \\
Pilgrimage Museum, \\
2 hotels, hotel rooms \\
in local convents \\
\end{tabular} \\
\hline Dukla & $\begin{array}{l}\text { St. John } \\
\text { from Dukla }\end{array}$ & $\begin{array}{l}\text { St. John from Dukla } \\
\text { Church }\end{array}$ & \begin{tabular}{|l|} 
Church \\
of St. John \\
in the Jungle, \\
chapel on Góra \\
Cergowa \\
\end{tabular} & $\begin{array}{l}\text { Convent of the } \\
\text { Bernardine } \\
\text { Fathers }\end{array}$ & $\begin{array}{l}\text { Religious items } \\
\text { for sale, } \\
\text { Franciscan Hotel } \\
\text { ( } 50 \text { beds) }\end{array}$ & $\begin{array}{l}\text { parish., } \\
\text { convent }\end{array}$ & developed & none \\
\hline Gniezno & St. Adalbert & $\begin{array}{l}\text { Cathedral of the } \\
\text { Mother of God and } \\
\text { St. Adalbert }\end{array}$ & $\begin{array}{l}\text { field altar, } \\
\text { church }\end{array}$ & $\begin{array}{l}\text { Archdiocesan } \\
\text { Museum }\end{array}$ & none & $\begin{array}{l}\text { Basilica of } \\
\text { the Head of } \\
\text { Poland's } \\
\text { Catholic } \\
\text { Church, } \\
\text { parish }\end{array}$ & developed & $\begin{array}{l}\text { Small sanctuary zone: } \\
\text { bookstore, hotel, } \\
\text { Palace of the Head of } \\
\text { Poland's Catholic } \\
\text { Church }\end{array}$ \\
\hline Gostyń & $\begin{array}{l}\text { Our Lady - } \\
\text { of the Holy } \\
\text { Rose }\end{array}$ & $\begin{array}{l}\text { Basilica of the } \\
\text { Immaculate } \\
\text { Conception and St. } \\
\text { Philip Neri }\end{array}$ & $\begin{array}{l}\text { retreat chapel } \\
\text { for } 200 \text { persons }\end{array}$ & $\begin{array}{l}\text { The Way of the } \\
\text { Cross (2006), } \\
\text { convent, chapel } \\
\text { by a miraculous } \\
\text { spring }\end{array}$ & $\begin{array}{l}\text { Retreat House } \\
\text { (120 persons) } \\
\text { with conference } \\
\text { room and coffee } \\
\text { bar }\end{array}$ & $\begin{array}{l}\text { parish, } \\
\text { convent }\end{array}$ & developed & none \\
\hline Kalisz & St. Joseph & $\begin{array}{l}\text { Church of the } \\
\text { Assumption with } \\
\text { a chapel with a } \\
\text { miraculous picture } \\
\text { of St. Joseph } \\
\end{array}$ & none & none & $\begin{array}{l}\text { Religious items } \\
\text { for sale }\end{array}$ & parish & basic & Pilgrims' hotel \\
\hline $\begin{array}{l}\text { Kalwaria } \\
\text { Zebrzy- } \\
\text { dowska }\end{array}$ & $\begin{array}{l}\text { Passion- } \\
\text { Marian }\end{array}$ & $\begin{array}{l}\text { Basilica with } \\
\text { a miraculous } \\
\text { picture of Our Lady } \\
\text { of the Calvary } \\
\end{array}$ & $\begin{array}{l}\text { Stations of the } \\
\text { Cross, } \\
\text { Bernardine } \\
\text { monastery } \\
\end{array}$ & $\begin{array}{l}\text { mobile Nativity } \\
\text { Scene }\end{array}$ & $\begin{array}{l}\text { Pilgrims' hotel, } \\
\text { restaurant, shop } \\
\text { with religious } \\
\text { items }\end{array}$ & convent & complex & Private rooms \\
\hline $\begin{array}{l}\text { Kraków- } \\
\text { Łagiewniki }\end{array}$ & \begin{tabular}{|l|} 
Convent \\
chapel with \\
a picture \\
of the \\
Merciful \\
Christ
\end{tabular} & $\begin{array}{l}\text { Basilica of God's } \\
\text { Mercy, Adoration } \\
\text { Chapel, Way } \\
\text { of the Cross, } \\
\text { Rosary Stations, } \\
\text { Chapel of the } \\
\text { Suffering Christ, } \\
\text { field altars } \\
\end{array}$ & $\begin{array}{l}\text { Convent of the } \\
\text { Sisters of Our } \\
\text { Lady of Mercy, } \\
\text { convent } \\
\text { cemetery }\end{array}$ & $\begin{array}{l}\text { Faustinum } \\
\text { Society building, } \\
\text { John Paul II Hall }\end{array}$ & $\begin{array}{l}\text { Observation } \\
\text { tower, information } \\
\text { desk }\end{array}$ & $\begin{array}{l}\text { convent, } \\
\text { education } \\
\text { center }\end{array}$ & complex & \begin{tabular}{|l|} 
Sanctuary zone: \\
shopping area, \\
Pilgrims' Hotel, coffee \\
bar, bar, conference \\
room, family \\
counseling, vendors \\
selling religious items, \\
convent headquarters, \\
private rooms
\end{tabular} \\
\hline
\end{tabular}


Tourism 2011, 21/1-2

\begin{tabular}{|c|c|c|c|c|c|c|c|c|}
\hline 1 & 2 & 3 & 4 & 5 & 6 & 7 & 8 & 9 \\
\hline $\begin{array}{l}\text { Kraków- } \\
\text { Mogiła }\end{array}$ & Holy Cross & $\begin{array}{l}\text { Church of the } \\
\text { Assumption and St. } \\
\text { Waclaw with a chapel } \\
\text { of the Miraculous } \\
\text { Crucifix }\end{array}$ & $\begin{array}{l}\text { Stations } \\
\text { of the Way } \\
\text { of the Cross, } \\
\text { field altar }\end{array}$ & convent & shop & $\begin{array}{l}\text { abbey, } \\
\text { parish }\end{array}$ & developed & none \\
\hline Leżajsk & $\begin{array}{l}\text { Our Lady } \\
\text { of Consolation }\end{array}$ & $\begin{array}{l}\text { Basilica of the } \\
\text { Visitation }\end{array}$ & $\begin{array}{l}\text { Leżajsk Way } \\
\text { of the Cross, } \\
\text { chapel in the } \\
\text { Pilgrims' Hotel }\end{array}$ & $\begin{array}{l}\text { Convent, Museum } \\
\text { of the Bernardine } \\
\text { Fathers' Province }\end{array}$ & $\begin{array}{l}\text { Pilgrims' Hotel built } \\
\text { in } 2002 \text { with } 117 \\
\text { beds, a conference } \\
\text { hall and a cafeteria }\end{array}$ & $\begin{array}{l}\text { convent, } \\
\text { parish }\end{array}$ & developed & none \\
\hline Limanowa & $\begin{array}{l}\text { Our Lady } \\
\text { of Sorrow }\end{array}$ & $\begin{array}{l}\text { Basilica of Our Lady } \\
\text { of Sorrow }\end{array}$ & $\begin{array}{l}\text { Short Way of the } \\
\text { Cross, field altar }\end{array}$ & none & $\begin{array}{l}\text { Pilgrims' Hotel ( } 85 \\
\text { beds) }\end{array}$ & parish & developed & none \\
\hline Nowy Sącz & $\begin{array}{l}\text { The Lord's } \\
\text { Transfiguration }\end{array}$ & $\begin{array}{l}\text { St. Margaret's } \\
\text { Basilica }\end{array}$ & none & none & none & parish & basic & none \\
\hline $\begin{array}{l}\text { Piekary } \\
\text { Śląskie }\end{array}$ & $\begin{array}{l}\text { Sanctuary } \\
\text { of Our Lady } \\
\text { of Piekary }\end{array}$ & $\begin{array}{l}\text { Basilica of the Mother } \\
\text { of God with } \\
\text { a miraculous picture } \\
\text { of Our Lady of } \\
\text { Piekary }\end{array}$ & $\begin{array}{l}\text { Stations of the } \\
\text { Cross, } 23 \text { Rosary } \\
\text { chapels, Way } \\
\text { of the Cross at } \\
\text { Rajski Square }\end{array}$ & Parish Museum & $\begin{array}{l}\text { Pilgrims' Hotel, } \\
\text { Pilgrims' Center, } \\
\text { coffee bar }\end{array}$ & parish & complex & $\begin{array}{l}\text { Hotel Górnik, } \\
\text { shop with } \\
\text { religious items }\end{array}$ \\
\hline Szczyrk & $\begin{array}{l}\text { Sanctuary } \\
\text { of Our Lady } \\
\text { the Queen } \\
\text { of Poland }\end{array}$ & $\begin{array}{l}\text { Church of Our Lady } \\
\text { the Queen of Poland }\end{array}$ & $\begin{array}{l}\text { Chapel } \\
\text { of Revelation }\end{array}$ & $\begin{array}{l}\text { Salesian convent, } \\
\text { Chapel of the } \\
\text { Mother of God }\end{array}$ & $\begin{array}{l}\text { Youth Hostel, } \\
\text { restaurant }\end{array}$ & convent & developed & none \\
\hline Trzebinia & $\begin{array}{l}\text { Our Lady } \\
\text { of Fatima }\end{array}$ & $\begin{array}{l}\text { Church of the Holy } \\
\text { Heart of Jesus Christ } \\
\text { with a chapel } \\
\text { dedicated to Our Lady } \\
\text { of Fatima }\end{array}$ & $\begin{array}{l}\text { The Way of the } \\
\text { Cross }\end{array}$ & $\begin{array}{l}\text { Monastery of the } \\
\text { Salvatorians, } \\
\text { Chapel of Our } \\
\text { Lady of Lourdes }\end{array}$ & Retreat House & $\begin{array}{l}\text { convent, } \\
\text { parish }\end{array}$ & developed & none \\
\hline Tuchów & $\begin{array}{l}\text { Our Lady } \\
\text { of Tuchów }\end{array}$ & $\begin{array}{l}\text { Basilica with } \\
\text { miraculous painting } \\
\text { of Mother of God }\end{array}$ & none & $\begin{array}{l}\text { convent, Mission } \\
\text { Museum (1975), } \\
\text { Sanctuary } \\
\text { Museum (1993), } \\
\text { Ethnographic } \\
\text { Museum (1997) } \\
\end{array}$ & $\begin{array}{l}\text { Shop with religious } \\
\text { items }\end{array}$ & parish & developed & Pilgrims' Hotel \\
\hline Wadowice & $\begin{array}{l}\text { Sanctuary } \\
\text { of Our Lady } \\
\text { of Perpetual } \\
\text { Help }\end{array}$ & $\begin{array}{l}\text { Basilica with an icon } \\
\text { of Our Lady of } \\
\text { Perpetual Help }\end{array}$ & none & none & none & parish & basic & none \\
\hline Wejherowo & $\begin{array}{l}\text { Dedicated } \\
\text { to the Mother } \\
\text { of God }\end{array}$ & $\begin{array}{l}\text { Church with a } \\
\text { miraculous picture } \\
\text { of Our Lady of } \\
\text { Wejherowo }\end{array}$ & $\begin{array}{l}26 \text { Way of the } \\
\text { Cross chapels }\end{array}$ & Church cellars & $\begin{array}{l}\text { Shop with religious } \\
\text { items }\end{array}$ & $\begin{array}{l}\text { Parish, } \\
\text { convent }\end{array}$ & complex & none \\
\hline Zakopane & $\begin{array}{l}\text { Our Lady } \\
\text { of Fatima }\end{array}$ & $\begin{array}{l}\text { Church of Our Lady } \\
\text { of Fatima with a figure } \\
\text { of Our Lady of Fatima }\end{array}$ & $\begin{array}{l}\text { Chapel of the } \\
\text { Immaculate } \\
\text { Heart of Mary, } \\
\text { Papal altar }\end{array}$ & $\begin{array}{l}\text { Prayer park with } \\
\text { Marian chapels, } \\
\text { Home of the } \\
\text { Pallottine Fathers }\end{array}$ & $\begin{array}{l}\text { Shop with religious } \\
\text { items }\end{array}$ & parish & developed & none \\
\hline
\end{tabular}

S o u r c e: author's own work based on fieldwork, research at sanctuaries, and BOZNAŃSKI et al. (2000), web pages of sanctuaries.

- complex sanctuary - consists of the sanctuary core and a complex of many buildings and sites (more than 5) designed to serve pilgrims - substantial numbers of non-religious activities.

In light of the above criteria, the following trends have been observed in a group of twenty national and international sanctuaries in Poland:

All international-class sanctuaries located in Polish cities are classified as complex sanctuaries. This includes Częstochowa, Kraków-Łagiewniki and Kalwaria Zebrzydowska. Hence, the greater the reach of a sanctuary, the more complex its organizational structure and the larger its pilgrim offering. Sanct- uaries dedicated to the crucifixion of Christ used to be the only complex sanctuaries, based on the criteria in this paper, due to their large number of chapels. Today the number of sites and attractions for pilgrims continues to increase and their variety is increasing as well. The trend towards the establishment of new types of sanctuaries and a richer pastoral programme is a general European trend. The Kraków-Łagiewniki Sanctuary is a part of this trend, as are a few other sanctuaries in Poland.

a) The Sanctuary of Jasna Góra is a particularly interesting case. It is a mediaeval sanctuary, which has been able to adapt its organizational structure to the 


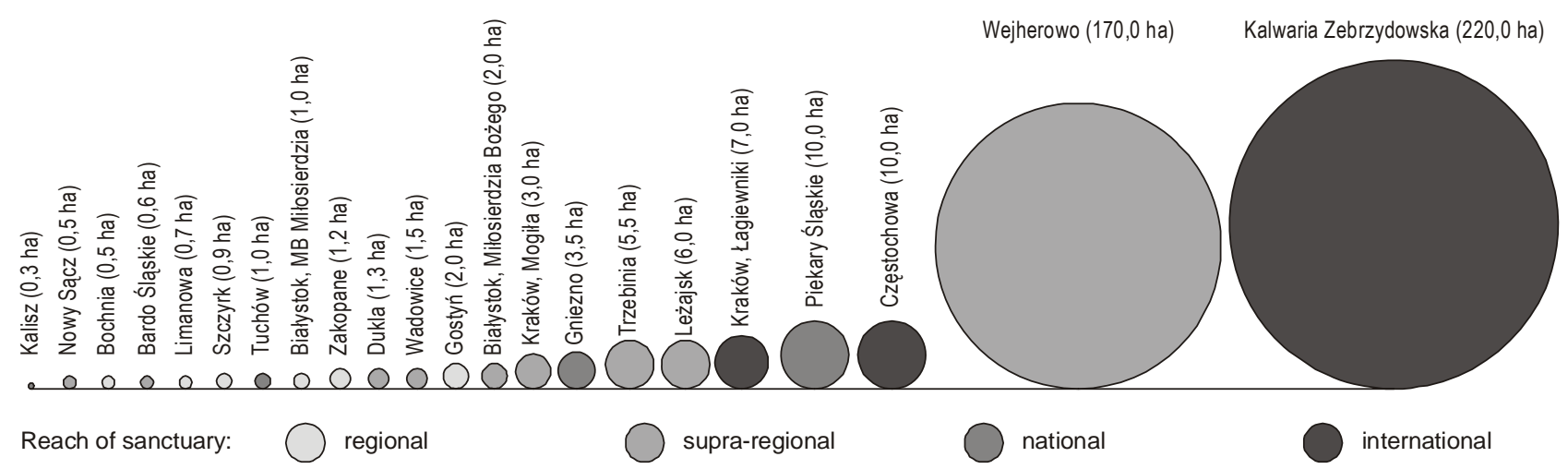

Fig. 1. Area of selected sanctuaries in Poland in 2010

S o u r c e: author's own work

needs of modern pilgrims in terms of cultural facilities (museums), religious features (Stations of the Cross next to the Monastery, Communion Hall, rosary stations) and educational facilities (audiovisual rooms).

b) Many regional and national sanctuaries are either original or basic sanctuaries. There are historical reasons for this. In times past, even large sanctuaries used to be just a single building without any special accommodation or attractions for pilgrims.

This paper is just a short summary of the various aspects of the organization of sacred space and focuses on the most important structural features of sanctuaries and their differences. A complex study of this subject would also involve an analysis of the cultural aspects of sanctuaries in order to show their tourism value and overall significance to the tourism industry in their parent settlements.

\section{EFFECT OF THE SANCTUARY ON THE ORGANIZATION OF URBAN SPACE}

A sanctuary's effect on its parent settlement may go beyond its own walls. The most important effect which we will call a macro-effect - is the establishment of new residential communities around the sanctuary, changes in existing residential communities, as well as adjacent communities gaining municipal status. Changes of this type occur over time and a relevant issue here is the rate of change. The Sanctuary of Jasna Góra has certainly had an impact on the development of the city of Częstochowa starting from the village of Częstochówka. Polish sanctuaries dedicated to the crucifixion of Christ were also instrumental in the development of some settlements in Poland (JACKOWSKI 2005). The Polish research literature even has a term for this phenomenon being known as Calvary settlements. This term applies to small towns founded primarily in the $17^{\text {th }} \mathrm{c}$. and the $18^{\text {th }} \mathrm{c}$. along with a sanctuary dedicated to the crucifixion of Christ. This includes Kalwaria Zebrzydowska, Góra Kalwaria, Pakość and Wejherowo. This type of settlement-sanctuary evolution is unique to Poland.

A close relationship between a sanctuary and a settlement may benefit both. In addition to the development of Old Częstochowa being aided by the Jasna Góra Sanctuary, another example of this type of beneficial relationship is that of Bardo Śląskie, whose development had been aided for centuries by pilgrims. However, it is important to remember that the founding of new settlements, and rapid urban growth driven by the presence of a sanctuary are not frequent occurrences and are generally associated with large pilgrimage centres.

The effect of a sanctuary on the organization of urban space is most readily visible in areas immediately adjacent to the sanctuary. This area is called a sanctuary zone and it is designed to meet the physical needs of pilgrims. This is an area of high pilgrim intensity and may include certain religious sites or institutions functioning in a complementary manner to the sanctuary itself. This zone is generally found only around the largest of sanctuaries due to the nature and magnitude of pilgrim 'traffic'. More than one million pilgrims are needed per year for a sanctuary zone to emerge. Other conditions include a fairly steady flow of pilgrims throughout the year, and pilgrims who choose to venture outside the sanctuary proper. Table 2 shows that only internationalclass sanctuaries possess tourism-type infrastucture in areas close to the sanctuary proper. Other sanctuaries feature only one or two additional buildings such as a hostel or giftshop. Even in the city of Gniezno - one of the earliest pilgrimage centres in Poland - there is only a small service zone near the Gniezno Sanctuary. 


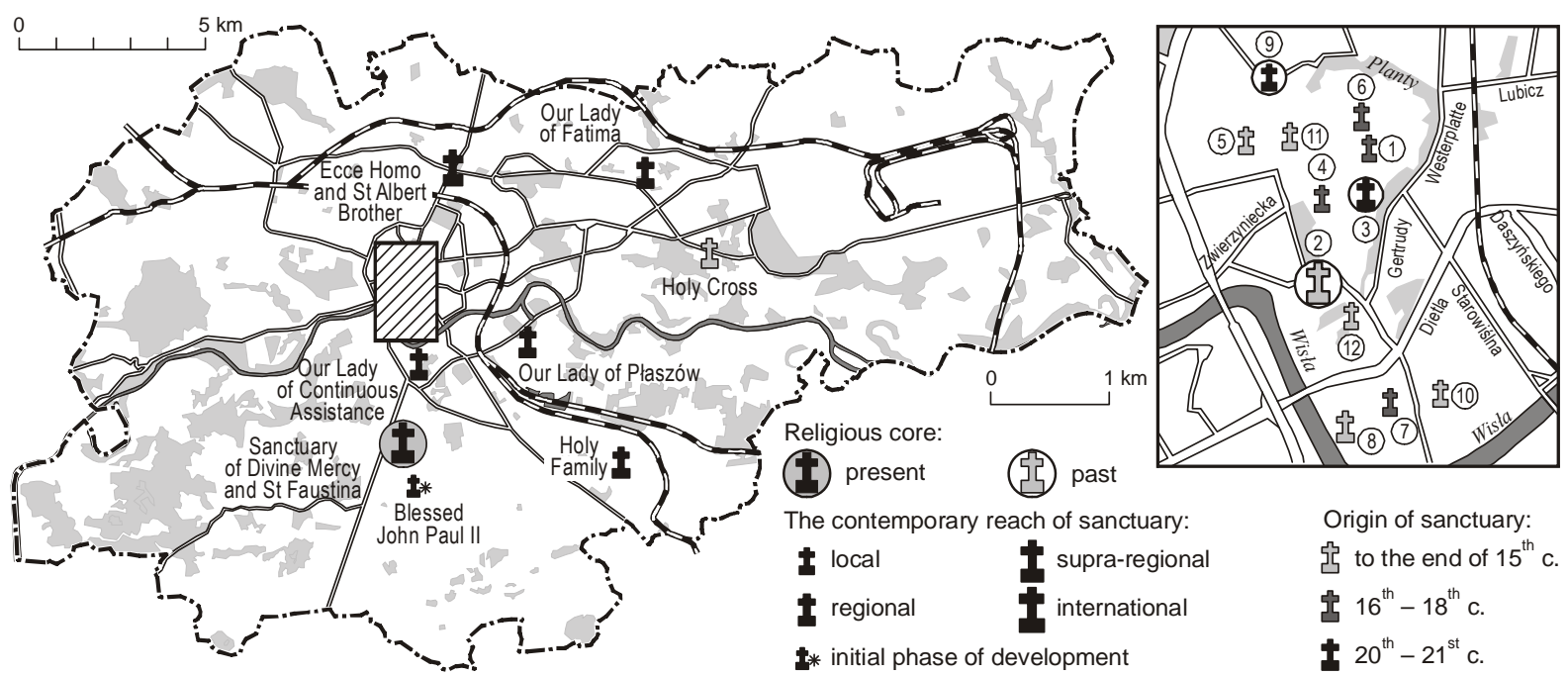

1 - MB Czestochowskiej, 2 - św. Stanisława bpa i św. Jadwigi, 3 - MB Różańcowej i św. Jacka, 4 - MB Bolesnej, 5 - Domek Loretański, 6 - MB od Wykupu Niewolników, 7 - MB Pocieszenia, 8 - św. Stanisława, 9 - MB Piaskowej, 10 - Sw. Stanisława Kazimierczyka, 11 - św. Jana Kantego, 12 - Szymona z Lipnicy

Fig. 2. Sanctuaries in Kraków

S o u r c e: author's own work

The sanctuary zones in Częstochowa and KrakówŁagiewniki are the best developed in Poland. Even so, they are much less developed than the sanctuary zones of those comparable in Western Europe (e.g. Lourdes, Fatima and Santiago de Compostela). Prior to the expansion of the Sanctuary of God's Mercy in Kraków, the only services available near the sanctuary were mini-stores and stalls along St. Faustyna Street. Today the sanctuary owns a hostel for pilgrims and a pastoral services centre which includes a restaurant, conference room, small stores and a parking area. The hostel is also home to the Catholic Family Life Centre (http://www.milosierdzie.pl/). In recent years, stalls with religious items and food items have appeared near the second entrance to the sanctuary Motarskiego Street (JACKOWSKI, SOŁJAN 2010).

In Częstochowa, the sanctuary zone rings the sanctuary itself (about $500 \mathrm{~m}$ ). The largest concentration of vendors and facilities serving pilgrims can be found along nearby Klasztorna Street. The sanctuary zone near Jasna Góra largely owes its existence to the initiative of the Pauline Fathers. Many of the facilities that serve pilgrims are located on Pauline-owned land and are run by the Pauline Fathers themselves. The Catholic Church operates about $80 \%$ of the hostel rooms in the sanctuary zone, the result of many religious orders renting out rooms to pilgrims wishing to stay close to the sanctuary.

The relationship between different sanctuaries located in the same city is also interesting from the perspective of urban space organization. Many large cities have more than one sanctuary. This is especially true of the city of Kraków, with more than a dozen sanctuaries since the Middle Ages. The importance of each sanctuary in Kraków has changed over the centuries. Wawel Cathedral was the religious core of the city between the $13^{\text {th }}$ and the $15^{\text {th }} \mathrm{c}$. and then again during the $19^{\text {th }}$ c. The Sanctuary of Our Lady of the Rosary and the Sanctuary of St. Hyacinth run by the Dominican Fathers constituted the religious core of the city between the $15^{\text {th }}$ and the $17^{\text {th }} \mathrm{c}$. The same was true of the Sanctuary of Our Lady of Piasek between the $17^{\text {th }}$ and $19^{\text {th }}$ c. Today the new Sanctuary of God's Mercy in Łagiewniki is becoming a new religious core outside the historic centre of Kraków (Fig. 2).

\section{CONCLUSION}

This article has attempted to show that a sanctuary can help alter urban space. A sanctuary is a very special place because of its religious nature and attracts both pilgrims and tourists. The spatial structure of a sanctuary is determined largely by changes in the number and nature of pilgrims. Modern pilgrimage centres are becoming more open to visitors who wish to take part in the life of a sanctuary, even if this involves non-religious activities. A sanctuary's religious offering is supplemented with typical tourism attractions while its establishment affects the development and spatial organization of a city in a variety 
of ways. Large sanctuaries favour the development of sanctuary service zones that cater to pilgrims and this is found in Poland. There are, however, some supraregional and regional sanctuaries that have few or no additional facilities designed for pilgrims.

\section{BIBLIOGRAPHY}

BOGUCKA, M., SAMSONOWICZ, H., 1986, Dzieje miast i mieszczaństwa w Polsce przedrozbiorowej, Zakład Narodowy im. Ossolińskich, Wrocław-Warszawa-Kraków.

BOZNAŃSKI, M., MIAZGA, D., NOWAK, M., WESTRYCH, M., WEŹRANOWSKA, K., ZAKRZEWSKI, R., 2000, Przewodnik pielgrzyma, wyd. Pascal, Bielsko-Biała.

DUDZIAK, J., 1983, Prawno-kanoniczna koncepcja sanktuarium, 'Tarnowskie Studia Teologiczne', t. 9, pp. 60-74.

ELIADE, M., 1993, Traktat o historii religii, Wyd. OPUS, Łódź.

JACKOWSKI, A., 1998, Pielgrzymki = turystyka pielgrzymkowa $=$ turystyka religijna? Rozważania terminologiczne, 'Turyzm', t. 8, pp. 5-20.

JACKOWSKI, A., 2005, Jasnogórskie pielgrzymowanie bez granic, wyd. Tygodnik Katolicki 'Niedziela', Częstochowa.

JACKOWSKI, A., SOŁJAN, I., 2008, Funkcja religijna i turystyczna ośrodków pielgrzymkowych, [in:] I. Jażdżewska (ed.), Funkcja turystyczna, XXI 'Konwersatorium Wiedzy o Mieście', t. 21, pp. 39-56.
JACKOWSKI, A., SOŁJAN, I., 2010, Rozwój sanktuarium Miłosierdzia Bożego w Krakowie-Łagiewnikach $i$ jego wptyw na przemiany przestrzenno-funkcjonalne dzielnicy Łagiewniki i Borek Fałęcki, [in:] S. Ciok, P. Migoń (eds), Przekształcenia struktur regionalnych. Aspekty społeczne, ekonomiczne i przyrodnicze, Uniwersytet Wrocławski, Instytut Geografii i Rozwoju Regionalnego.

KŁOCZOWSKI, J., 1987, Od pustelni do wspólnoty: grupy zakonne $w$ wielkich religiach świata, Czytelnik, Warszawa.

Maty stownik religioznawczy, 1969, Z. Poniatowski (ed.), Wiedza Powszechna, Warszawa.

Miasta polskie w tysiącleciu, 1965, M. Siuchniński (ed.), Zakład Narodowy im. Ossolińskich, Wrocław, Warszawa, Kraków.

Miejsca święte Rzeczypospolitej. Leksykon, 1998, A. Jackowski (ed.), Znak, Kraków.

MitKOWSKA, A., 2001, Sacrum w krajobrazie, [in:] K. Pawłowska (ed.), Architektura krajobrazu a planowanie przestrzenne. Podręcznik dla studentów wyższych szkót technicznych, Politechnika Krakowska im. T. Kościuszki, Kraków, pp. 227-238.

PARK, C., 1994, Sacred Worlds. An introduction to geography and religion, Routledge, Londyn.

RINSCHEDE, G., 1995, The Pilgrimage Centre of Loreto, Italy: A Geographical Study, [in:] D.P. Dubey (ed.), Pilgrimage Studies. Sacred Places. Sacred Traditions, The Society of Pilgrimage Studies Allahabad, pp. 157-178.

Stownik jezzyka polskiego, 1983, M. Szymczak (ed.), PWN, Warszawa.

www.klasztor.tuchow.pl (15.09.2011).

www.trzebinia.sds.pl (15.09.2011).

www.sankt_bardo.opoka.net.pl (15.09.2011).

www.jasnagora.pl (2.10. 2011).

www.kalwaria.eu (15.09.2011).

www.filipini.gostyn.pl/sanktuarium (10.09.2011). 